\title{
Distribution and recent status of freshwater mussels of family Unionidae (Bivalvia) in the Czech Republic
}

\author{
Luboš Beran* \\ Nature Conservation Agency of the Czech Republic, Regional Office Kokořínsko - Máchuv kraj Protected Landscape Area \\ Administration, Česká 149, 27601 Mělník, Czech Republic
}

Received: 22 March 2019 / Accepted: 30 September 2019

\begin{abstract}
This study is devoted mainly to the distribution and its changes, inhabited and preferable habitats of bivalves from family Unionidae in the territory of the Czech Republic and the discussion of major threats and conservation measures. Altogether 6 autochthonous (Unio crassus, Unio pictorum, Unio tumidus, Anodonta anatina, Anodonta cygnea, Pseudanodonta complanata) and 1 allochthonous species (Sinanodonta woodiana) has been known in the Czech Republic. All these species occurred in all three river basins (Labe, Odra, Danube) and watersheds (North, Baltic and Black seas). A. anatina is the most widespread and common unionid while $P$. complanata is an autochthonous bivalve with the most restricted area of distribution. U. crassus has been a significantly disappearing species. As in most European countries, pollution and habitat loss including fragmentation and degradation, together with other factors such as water abstraction, invasive species and loss of fish hosts are the main threats affecting their populations.
\end{abstract}

Keywords: Mollusca / Bivalvia / distribution / threats / Czech Republic

Résumé - Répartition et état récent des moules d'eau douce de la famille des Unionidae (Bivalvia) en République Tchèque. Cette étude est principalement consacrée à la répartition et à ses changements, aux habitats occupés et préférés des bivalves de la famille des Unionidae sur le territoire de la République Tchèque et à la discussion des principales menaces et mesures de conservation. Au total, 6 espèces autochtones (Unio crassus, Unio pictorum, Unio tumidus, Anodonta anatina, Anodonta cygnea, Pseudanodonta complanata) et 1'espèce allochtone (Sinanodonta woodiana) sont connues en République Tchèque. Toutes ces espèces étaient présentes dans les trois bassins hydrographiques (Labe, Odra, Danube) et bassins versants (Mer du Nord, Mer Baltique et Mer Noire). A. anatina est l'unionidé le plus répandu et le plus commun tandis que $P$. complanata est un bivalve autochtone dont la répartition est la plus restreinte. U. crassus est une espèce en voie de disparition. Comme dans la plupart des pays européens, la pollution et la perte d'habitat, y compris la fragmentation et la dégradation, ainsi que d'autres facteurs tels que les prélèvements d'eau, les espèces envahissantes et la perte de poissons hôtes sont les principales menaces qui pèsent sur leurs populations.

Mots clés : Mollusque / Bivalve / distribution / menaces / République Tchèque

\section{Introduction}

Family Unionidae Rafinesque, 1825 with approximately 700 species is the most common family of the Order Unionida Gray, 1854 containing about 900 species. North America is the continent with the highest diversity of this family with nearly 300 species (Williams et al., 1993; Lopes-Lima et al., 2018) while 14 autochtonous species are mentioned from Europe by Lopes-Lima et al. (2017). However, it can be assumed that

\footnotetext{
*Corresponding author: lubos. beran@nature.cz
}

recent and further molecular studies will change this number as confirmed by Araujo et al. (2018) who distinguished 11 species of genus Unio in Europe and other 3 species in surrounding areas (Northern Africa, Izrael, Turkey). One non-native species Sinanodonta woodiana (Lea, 1834) also occurs in Europe. This species native to East and South-East Asia was introduced to Europe with fishes in 1963 (Watters, 1997) and is known from most of European countries (e.g. Welter-Schultes, 2012). Many species of this family are critically endangered or nearly extinct especially in North America (Williams et al., 1993) but decline of many populations has also been documented in the case of Europe's freshwater mussels. That 


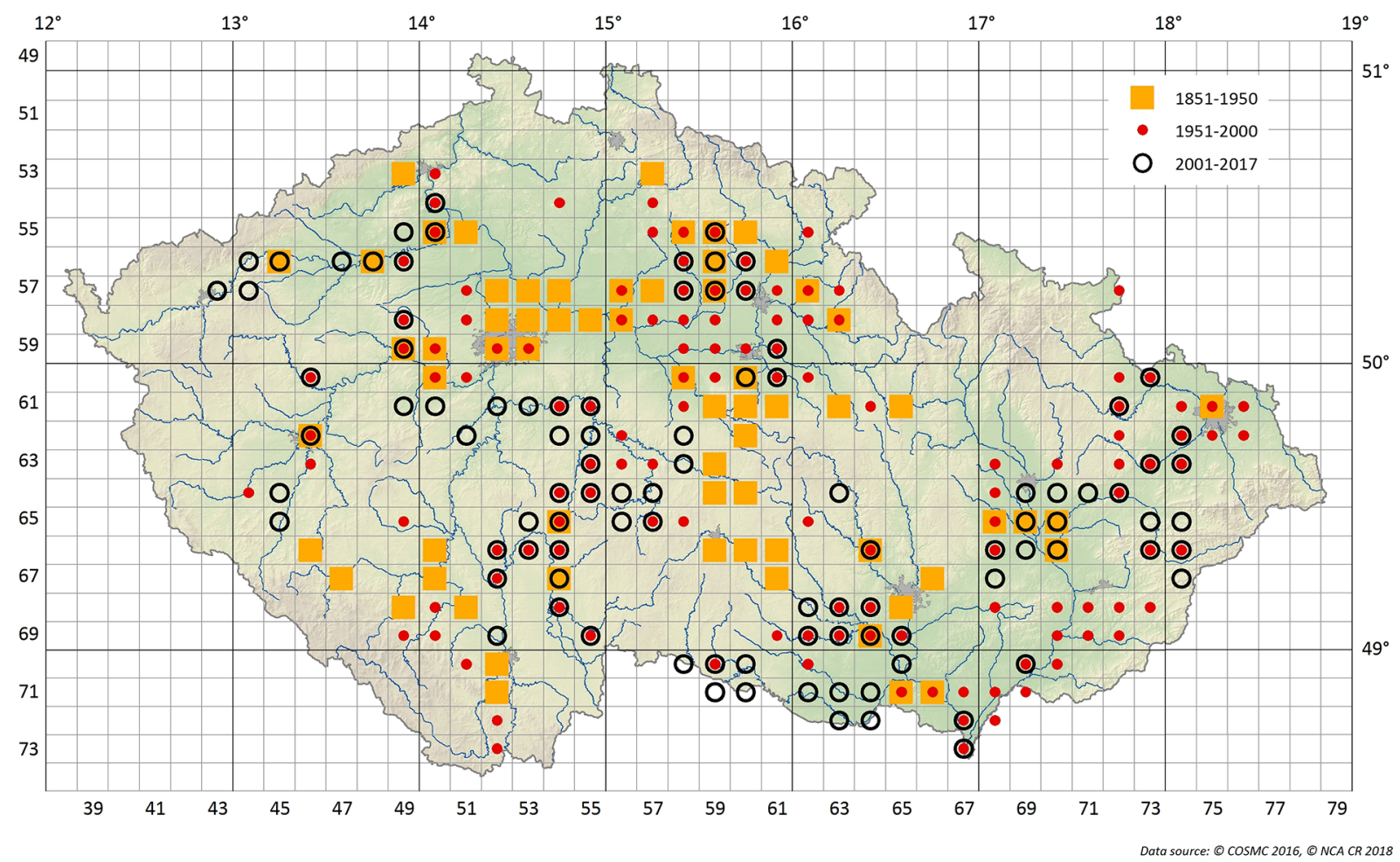

Fig. 1. Distribution of Unio crassus in the mapping fields for faunistic mapping in the Czech Republic. All maps drawn by J. Vrba.

is why freshwater mussels have received increasing attention in last decades (Lopes-Lima et al., 2017).

The current status of freshwater mussels of order Unionida in Europe has been summarized by Lopes-Lima et al. (2017). This article and the quantity of distributional data were the main reasons for the more detailed study for the territory of the Czech Republic presented below.

The main objectives of this study were to: (a) use the large amount of distributional data for construction of distributional maps of particular unionids in different time periods, (b) use distributional data (or its part) for identifying inhabited and preferable habitats, (c) analyse changes of distribution for unionids in general as well as for particular species and (d) discuss anthropogenic factors affecting distribution of unionids including major threats and conservation measures. No similar study has been published for the territory of the Czech Republic yet despite the fact that a great deal of attention is being paid to this group in some neighbouring states (e.g. Germany). The main intent of this study was to report the information about current situation in the Czech Republic and support the conservation of unionids and their habitats.

This work is only focused on species of the family Unionidae because most species except Unio crassus Philipsson, 1788 have been neglected while Margaritifera margaritifera (Linnaeus, 1758), the only representative of family Margaritiferidae, has been studied in detail elsewhere (e.g. Hruška, 1992; Hruška and Volf, 2003; Simon et al., 2015) and the management plan has been prepared for this mussel (AOPK, 2013).

\section{Materials and methods}

Data used in this paper was obtained from two main sources. The first one was author's database containing more than 62,000 records about the occurrence of freshwater molluscs in the Czech Republic. This data has been obtained by his own field research since 1993 and from many published and unpublished papers, private collections and collections in museums dating from 1825 onwards. Altogether 34,846 of these records were obtained in the most recent time period (2001-2017) while 21,562 were from time period of 19512000 and only 6381 were from the period of $1851-1950$. The second important source was the database (NDOP) of the Nature Conservation Agency of the Czech Republic containing more than 73,000 records about the occurrence of aquatic and terrestrial molluscs. Most of them $(47,572)$ were obtained between 2001 and 2017 while 28,049 records were available for period of 1951-2000 and only 2116 records for period of 1851-1950. However, it should be noted that in this case the database also contains data that was not obtained or revised by experienced malacologists and some of it could be dubious. That is a reason why only reliable data from this database was used. Several recent data entries were obtained also from database of Michal Horsák, other published or unpublished papers. Data has been used to create maps (Figs. 1-7) of distribution of particular species in fields for faunistic mapping (Pruner and Míka, 1996) in different time periods (1851-1950, 1951-2000, 2001-2017) and also for creating Figure 8.

Data in mentioned databases has been obtained from different sources (field researches, published and unpublished papers, collections in museums or private collections) and therefore it varied greatly in quality. Some data entries were accurately localized using geographical coordinates. However, especially with older data entries it was only possible to locate them into fields of Central European mapping grid-cell systems based on the site GPS coordinates (Pruner and Míka, 1996). 


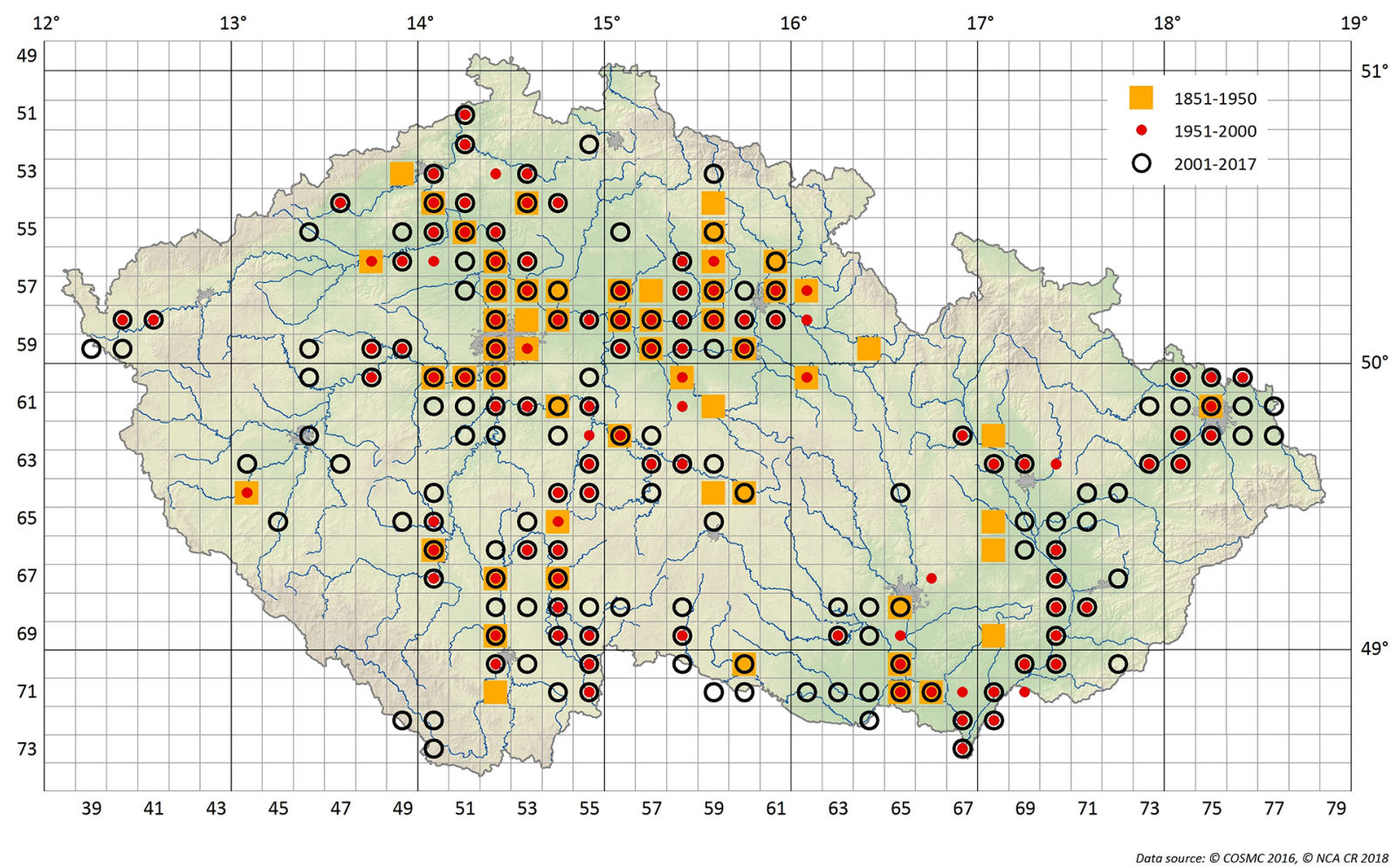

Fig. 2. Distribution of Unio pictorum in the mapping fields for faunistic mapping in the Czech Republic.

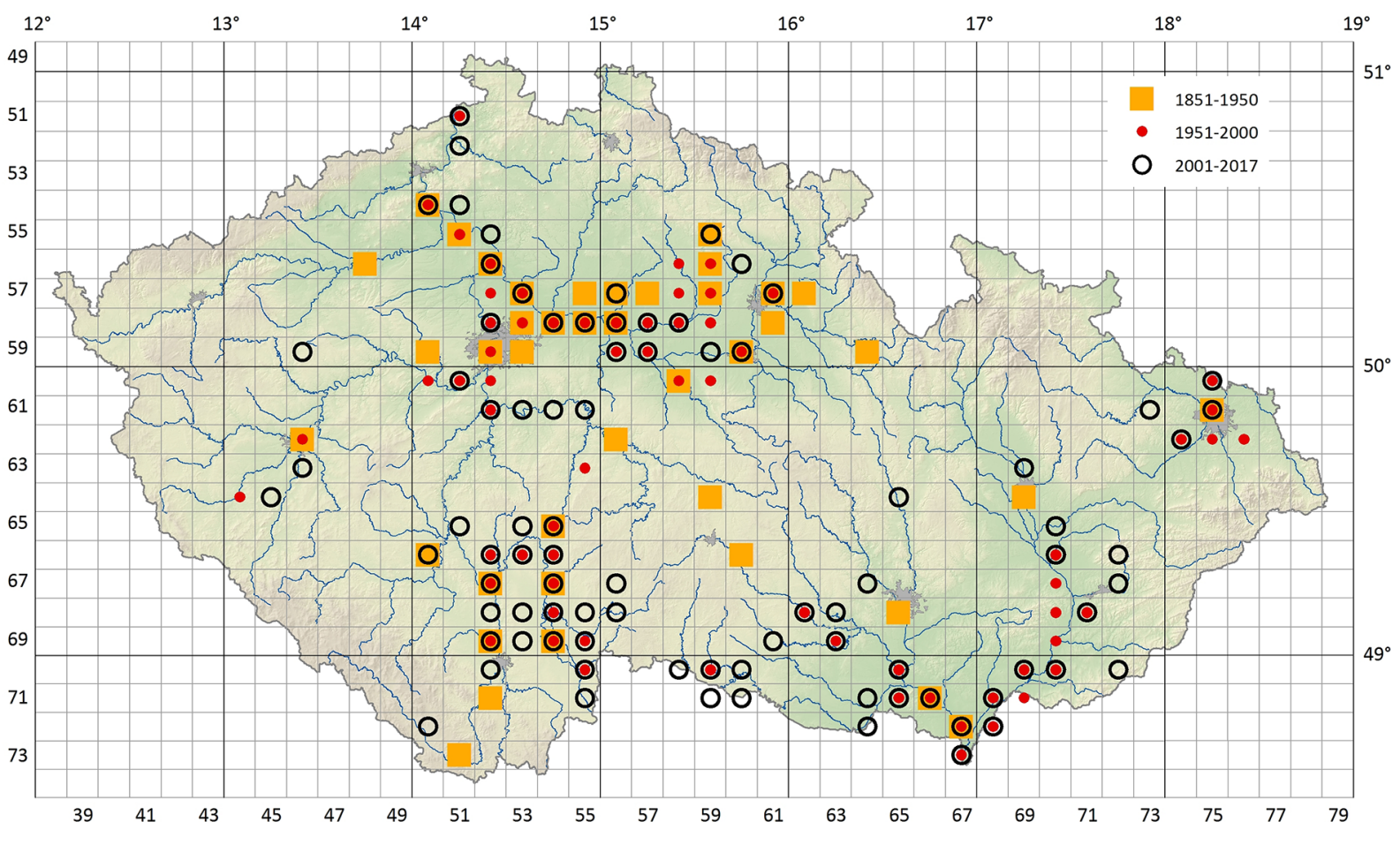

Fig. 3. Distribution of Unio tumidus in the mapping fields for faunistic mapping in the Czech Republic.

Most of field data was obtained from different faunistic researches based on freshwater molluscs which did not specifically target unionids. Only a part of the data (mostly own author's data from 1993 onwards) contained more information other than presence of particular species, for example an estimation of population density rather than just a number of recorded or collected specimens. It was the reason why only own author's data was used for creating 


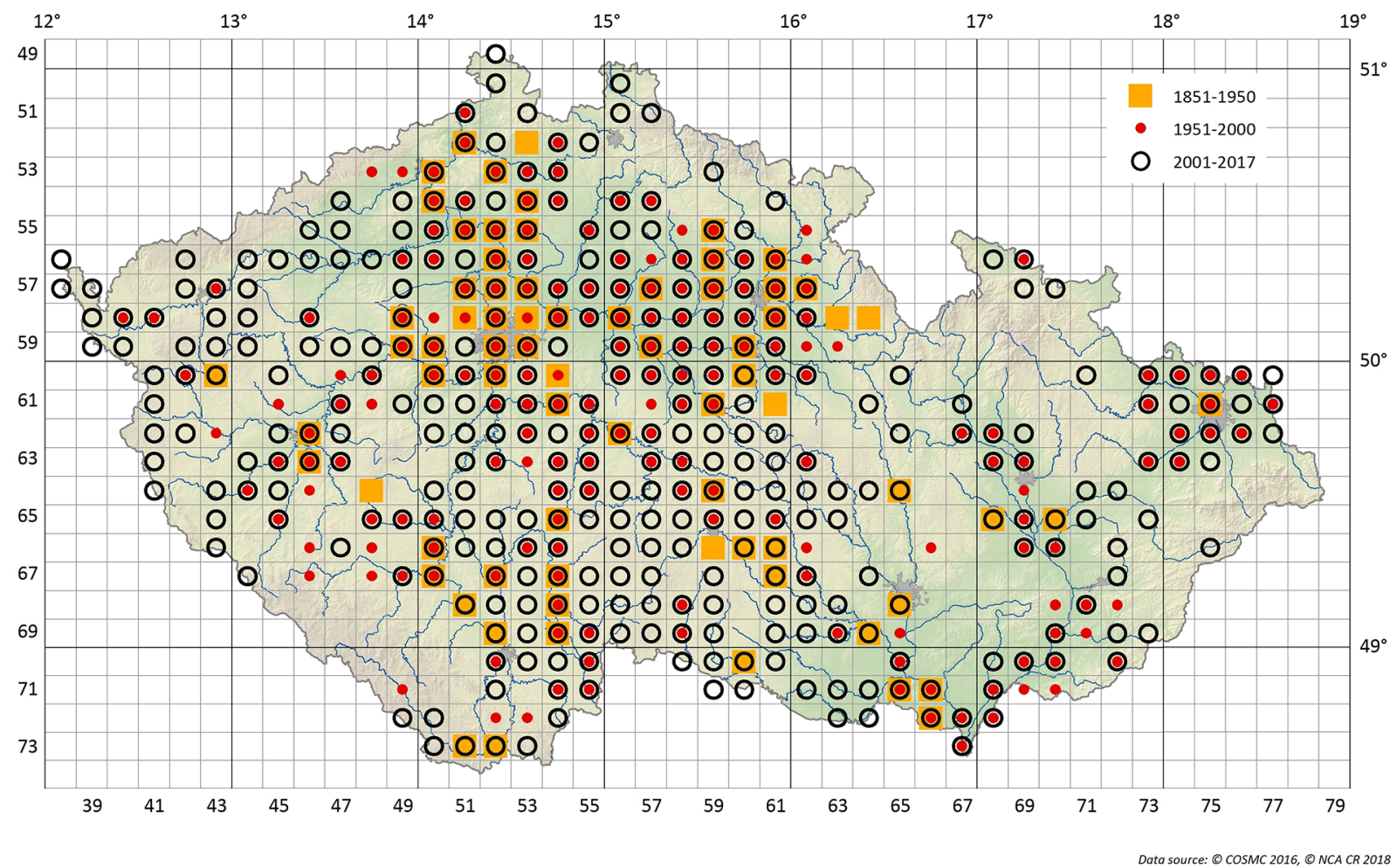

Fig. 4. Distribution of Anodonta anatina in the mapping fields for faunistic mapping in the Czech Republic.

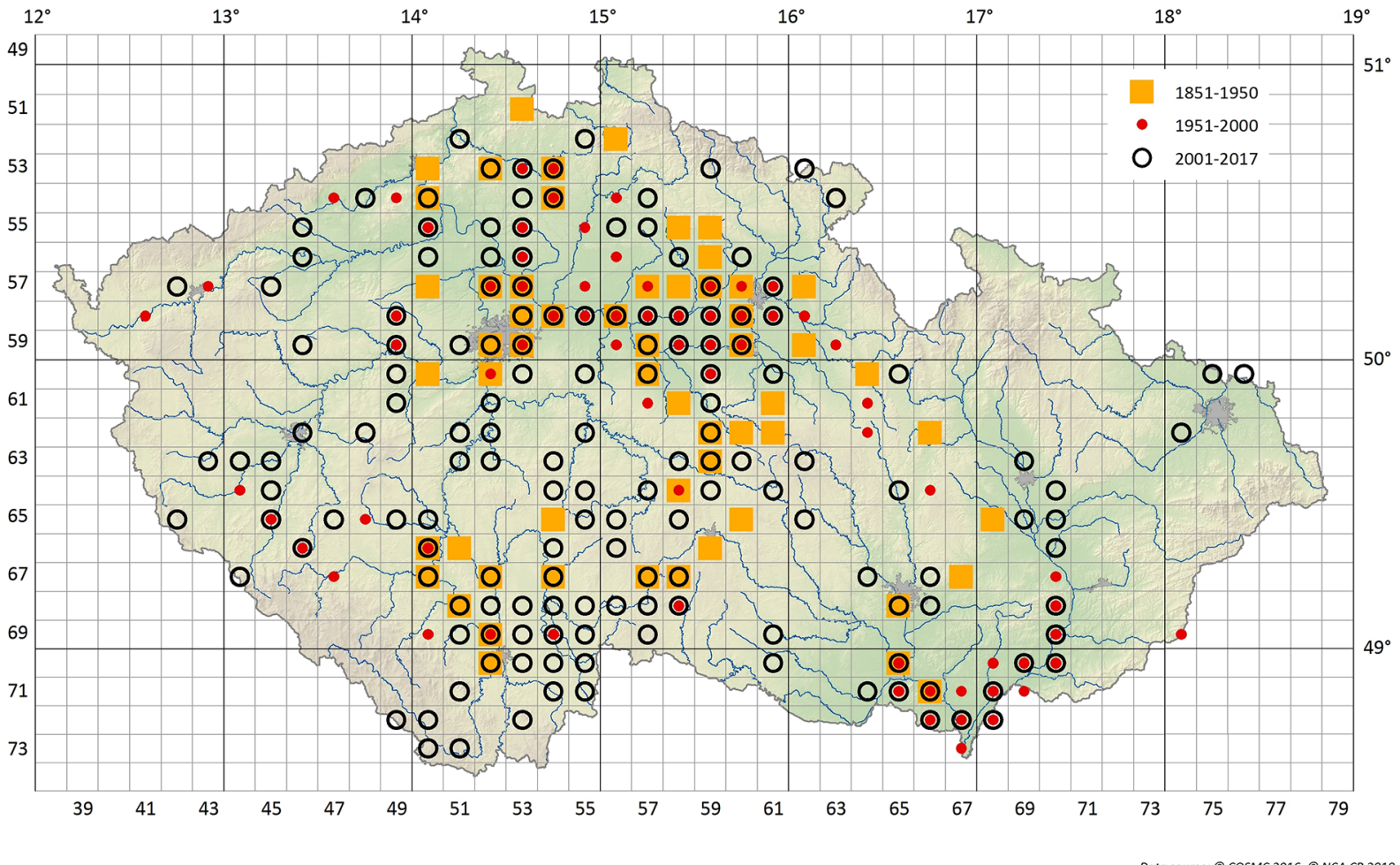

Fig. 5. Distribution of Anodonta cygnea in the mapping fields for faunistic mapping in the Czech Republic. 


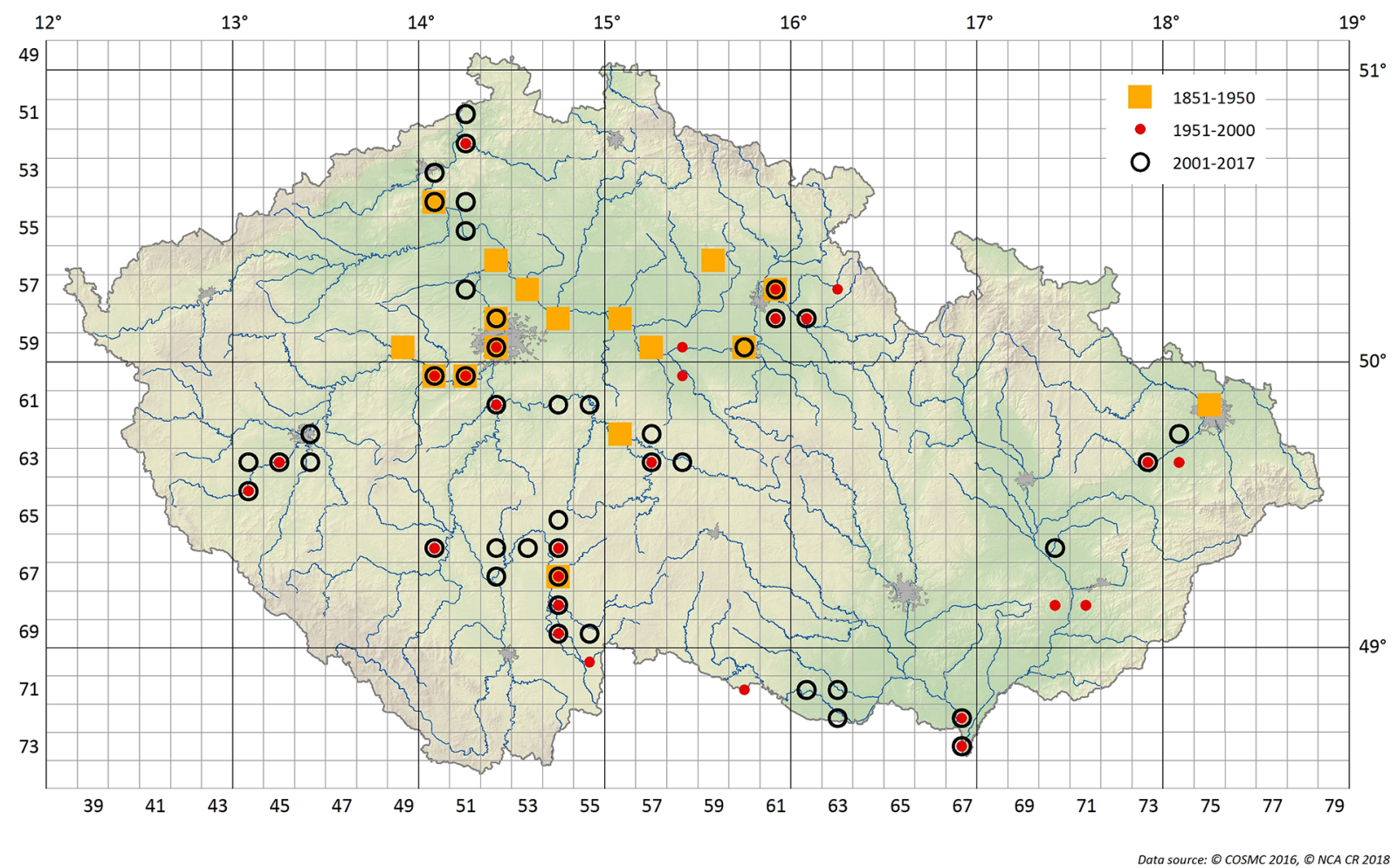

Fig. 6. Distribution of Pseudanodonta complanata in the mapping fields for faunistic mapping in the Czech Republic.

Figure 10. This data contained at least an estimation of density of population divided into three categories (less than 1 specimen $/ \mathrm{m}^{2}, 1-10$ specimens $/ \mathrm{m}^{2}$, more than 10 specimens $/ \mathrm{m}^{2}$ ).

Only data from author's database was used for creating of Figure 9 and for analysis of occurred habitats (Fig. 11). The reason for this was that in the other sets of data it was often not possible to accurately identify the type of habitat in which the specimens occurred. The habitats were classified into six coarse habitat categories as follows: the 7th- and 9th-order rivers according to the Strahler stream order system (hereafter named as Large rivers, parts of bigger rivers usually wider than $15 \mathrm{~m}$ ); all the other running waters (Small watercourses); natural or semi-natural standing water bodies such as pools, river arms, oxbows etc. (Oxbows); artificial deep water reservoirs (Dam reservoirs); artificial shallow reservoirs used mostly for fish breeding (Fishponds); water bodies created by mining such as quarries and sandpits (Sandpits).

A review of published and unpublished papers together with author's experiences obtained during field research in last 25 years were used to discuss anthropogenic factors affecting distribution of unionids in the territory of the Czech Republic including major threats and conservation measures. Finally, a table with a qualitative assessment of the risk of particular threat to each species was created on the basis of the data presented in this study, published and unpublished papers cited in this study and using author's professional judgment.

\subsection{Aquatic habitats of the Czech Republic}

The Czech Republic is situated in the upper sections of the river basins of the large rivers and thus there are no large watercourses. Only three respectively four bigger rivers belonging to three different watersheds (North, Baltic and Black sea) leave the Czech Republic. The largest river is the Labe (Elbe), which drains the western part of the Czech Republic with an average flow of $319 \mathrm{~m}^{3} / \mathrm{s}$ at the boundaries between the Czech Republic and Germany. Rivers Dyje (Thaya) and Morava (March) belonging to the Danube river basin have an average flow of 36 and $61 \mathrm{~m}^{3} / \mathrm{s}$ near their confluence, forming the border among the Czech Republic, Slovakia and Austria. These rivers drain most of the eastern part of the Czech Republic, while the Odra drains the northeastern part of the Czech Republic with average flow $42 \mathrm{~m}^{3} / \mathrm{s}$ at the boundaries between the Czech Republic and Poland.

In the Czech Republic there are practically no natural lakes suitable for unionids and natural oxbows and pools exist mostly in floodplains of large rivers. There are about 21,000 fishponds and more than 100 dams in the Czech Republic. Flooded quarries and especially sandpits in lower altitudes are other numerous anthropogenic aquatic habitats suitable for unionids. At present large lakes are formed by the flooding of quarries after coal mining (e.g. lake Medard with 493 ha, Fig. 27).

The Czech Republic has a rugged surface and compared to other Central European states the rugged surface occupies most of the territory. Less than one fifth of the area of Czech Republic could be considered flat. The average altitude of the Czech Republic is $430 \mathrm{~m}$ above sea level while the average altitude of Europe is $290 \mathrm{~m}$. The lowest point of the Czech Republic is the Labe (Elbe) at Hřensko $(115 \mathrm{~m}$ a. s. 1.) on the Czech-German boundaries. 


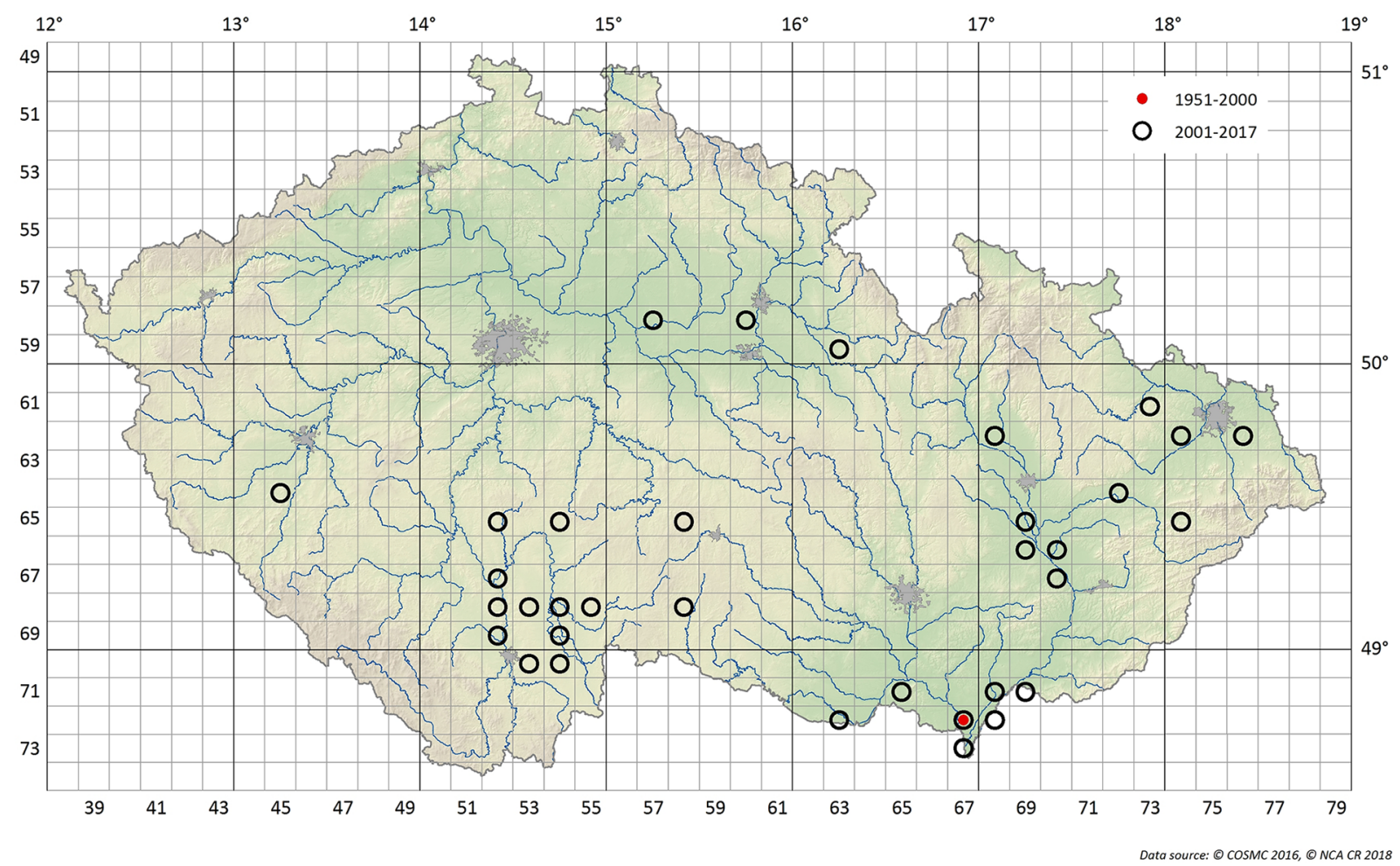

Fig. 7. Distribution of Sinanodonta woodiana in the mapping fields for faunistic mapping in the Czech Republic.

\section{Results}

\subsection{Distribution and changes in distribution}

Altogether 7 species ( 6 autochthonous, 1 allochthonous) of family Unionidae have been known from the territory of the Czech Republic. The genus Unio is represented by three species. The most widespread has been Unio crassus (Fig. 1). Unio pictorum (Linnaeus, 1758) (Fig. 2) has also been a widespread bivalve known from a large part of the Czech Republic. Unio tumidus Philipsson, 1788 is restricted predominantly to lowlands along larger rivers (Labe, Odra, Dyje, Morava) and floodplains of rivers Vltava, Lužnice and Nežárka in South Bohemia (Fig. 3).

Two species of genus Anodonta have occurred in the Czech Republic. Anodonta anatina (Linnaeus, 1758) is the most widespread and common unionid (Fig. 4) while Anodonta cygnea (Linnaeus, 1758) is significantly rarer (Fig. 5). Pseudanodonta complanata (Rossmäessler, 1835) is the bivalve with the most restricted distribution of all autochthonous species of family Unionidae in the Czech Republic. Its occurrence has been known only from rivers or their parts e.g. Labe, Vltava, Radbuza, Úhlava, Berounka, Sázava, Orlice, Otava, Lužnice, Nežárka, Chrudimka, Morava, Dyje, Odra (Fig. 6).

Sinanodonta woodiana is the last species of family Unionidae occurring in the Czech Republic. This non-native species has inhabited southern parts of the Czech Republic (South Bohemia, South and Central Moravia) while in other parts it is rare so far. An overview of number of mapping fields with occurrence of particular species is showed in Table 1.

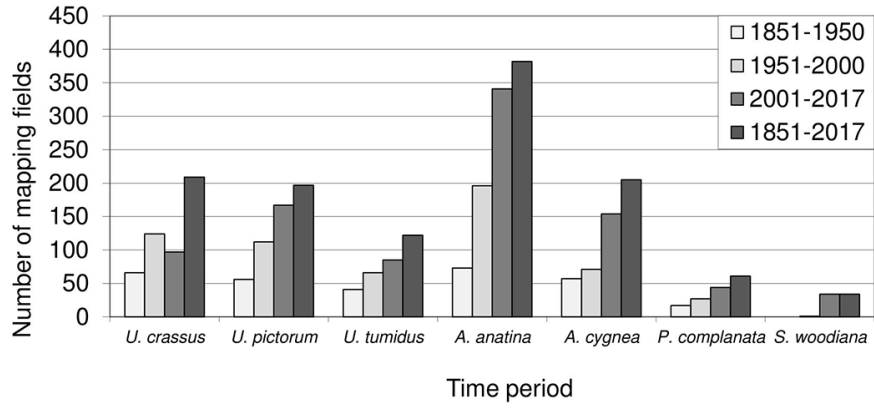

Fig. 8. The number of mapping fields with the occurrence of particular species.

The number of mapping fields in each time period is increasing for all species except $U$. crassus as shown in Figure 8 . The number of records is increasing for all species (Fig. 9).

The data about occurrence of $P$. complanata in the central section of the Labe (Elbe) River exist from the first time period (1851-1950) only.

\subsection{Populations}

Author's own data obtained by field research from 1993 onwards contained an estimation of density of population divided into three categories and allowed to evaluate the density of unionids in the Czech Republic. The low population densities of unionids were documented in most cases as shown in Figure 10. The population densities of individual species 


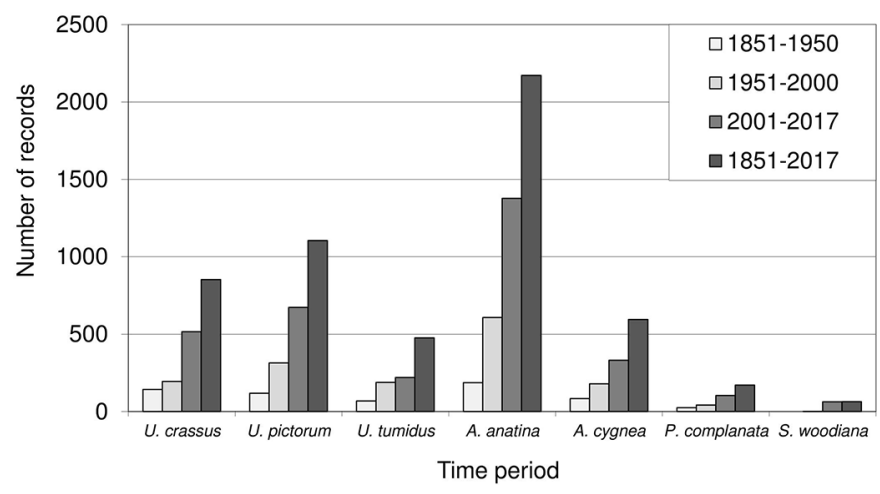

Fig. 9. The number of records of particular species from author's database.

Table 1. Number of mapping fields with occurrence of particular species. $100 \%=676$ mapping fields.

\begin{tabular}{lll}
\hline Species & Num. of m. fields & $\%$ \\
\hline Unio crassus & 209 & 31 \\
Unio pictorum & 197 & 29 \\
Unio tumidus & 122 & 18 \\
Anodonta anatina & 382 & 57 \\
Anodonta cygnea & 205 & 30 \\
Pseudanodonta complanata & 61 & 9 \\
Sinanodonta woodiana & 34 & 5 \\
\hline
\end{tabular}

were less than 1 specimen $/ \mathrm{m}^{2}$ in most cases. For each species this category accounted between $70 \%$ (U. tumidus) and $97 \%$ (P. complanata). In the case of $U$. tumidus a relatively high proportion of populations had densities of 1-10 specimens $/ \mathrm{m}^{2}$. Conversely, populations with a density more than 10 specimens $/ \mathrm{m}^{2}$ were not found in the cases of $P$. complanata and $S$. woodiana and this category accounted only $2-6 \%$ for other species. The highest abundance of population of endangered $U$. crassus was recorded mostly in small watercourses (e.g. Lukavecký potok Brook, Fig. 17) and mainly in artificially created canals (canal Strhanec, canal in Hovězí, Fig. 19, canal in Vsetín) of the Bečva River in Moravia. Only in a few cases were high-density populations found in the middle course of the Dyje River. The highest density $\left(225\right.$ specimens $\left./ \mathrm{m}^{2}\right)$ of this species known in the Czech Republic was recorded in the canal of the Vsetínská Bečva River in Vsetín mentioned above.

\subsection{Habitats}

Suitable natural habitats for unionids in the Czech Republic are primarily watercourses from smaller streams to the largest rivers. The Czech Republic is situated in the upper sections of the river basins of the large rivers and this is the reason for the absence of large watercourses. U. crassus and $P$. complanata significantly prefer running waters and their occurrence in other habitats is rare (Fig. 11). U. crassus inhabits rather smaller watercourses (Figs. 16-19) while $P$. complanata is a typical species in larger rivers (Figs. 12-15). In general running waters are clearly the preferred habitat of all

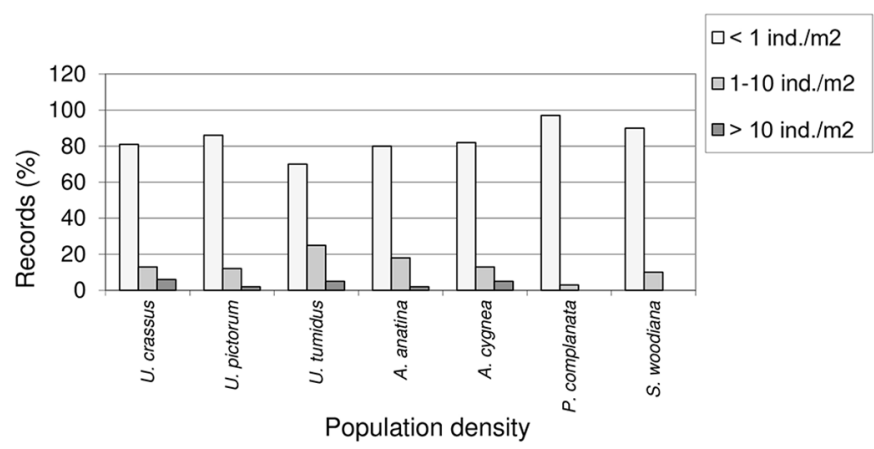

Fig. 10. Population density of particular species.

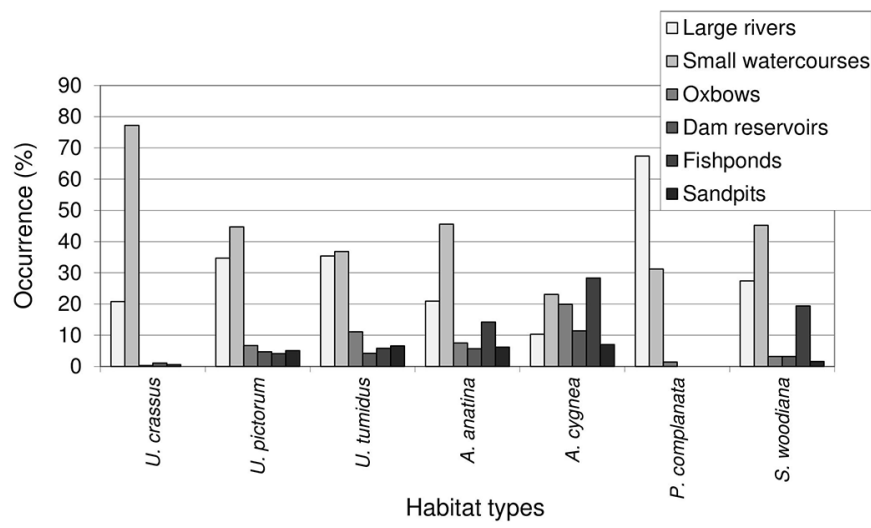

Fig. 11. Habitat preference of particular species.

species of the family Unionidae except of $A$. cygnea (Fig. 11). In comparison with other species $A$. cygnea prefers standing waters, especially ponds but also pools, oxbows and dam reservoirs. Together with $A$. anatina and $S$. woodiana it is a common unionid in fishponds (Figs. 24-25) while the occurrence of Unio in these habitats is rare. Another artificial habitat is dam reservoirs (Figs. 22-23). Dams built on upper sections of some rivers are the only habitat of standing waters inhabited by Unio crassus. Dams on large rivers are usually inhabited by more diverse communities. Numerous populations of non-native $S$. woodiana have been recently found here, especially in South Bohemia. More extensive reservoirs created by mining such as quarries and sandpits (Figs. 26-27) are also suitable for unionids. Sandpits in lowlands in floodplains of larger rivers are inhabited by A. cygnea, A. anatina, U. pictorum, U. tumidus and occasionally also by $S$. woodiana.

\section{Discussion}

\subsection{Distribution}

The different affinity especially to altitude and associated natural factors is visible from most of maps. $U$. crassus probably originally inhabited an extensive part of the Czech Republic from lowlands to foothills and was the most widespread from all three species of genus Unio. In comparison with the previous species in the case of 

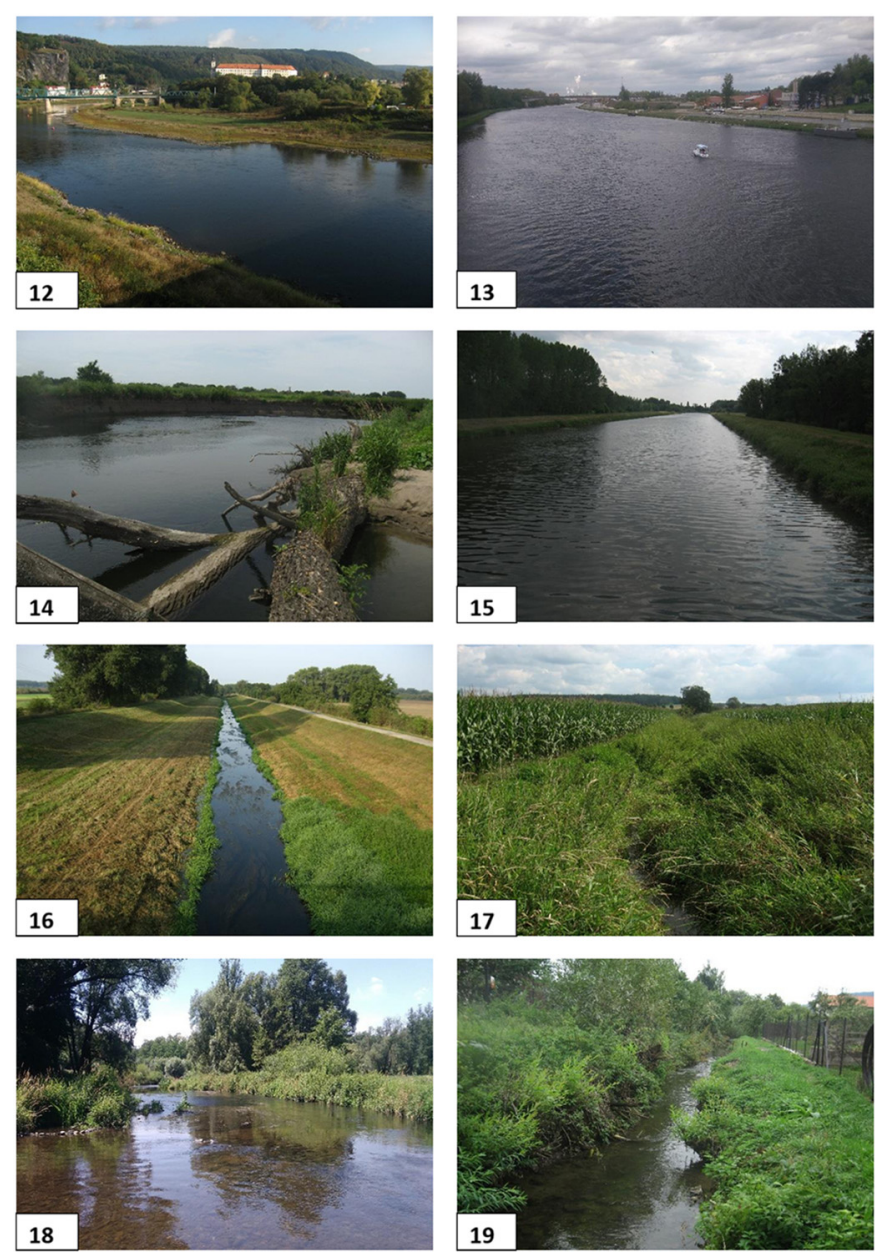

Figs. 12-19. Running waters. 12-15 Large rivers. 12-Labe (Elbe) River in Děčín (near Czech - German boundary). Only short section of this river has a relatively natural character but the construction of the weir has been prepared. U. pictorum, A. anatina. 13-Labe (Elbe) River in Mělník. The major part of this river has been changed by weirs in slowly flowing shipping canal. U. pictorum, A. anatina. 14Dyje River downstream of Břeclav (Czech - Austrian boundary). This river has a natural character in this section. U. crassus, $U$. pictorum, U. tumidus, A. anatina, A. cygnea, P. complanata, $S$. woodiana. 15-Svratka River upstream of the Nové Mlýny dam water reservoirs was drastically regulated. U. pictorum, U. tumidus, A. anatina. 16-19 Small watercourses. 16-Jevišovka River near Hrušovany nad Jevišovkou. The major part of smaller watercourses has been regulated in the same way as this river. U. pictorum, $U$. tumidus, A. anatina. 17-Lukavecký potok Brook. Many small watercourses are situated in intensively cultivated landscape surrounded by arable land. Abundant population of $U$. crassus. 18-Oslava River near Oslavany. U. crassus, A. anatina. 19-artificial canal of the Bečva River near Hovězí has been inhabited by an abundant population of $U$. crassus.

U. pictorum an affinity to lower altitudes is evident. U. tumidus inhabits mostly lowlands of big rivers. The occurrence of Anodonta anatina is known from lowlands to mountains except for the highest altitudes and it is the most widespread species of family Unionidae. Its absence in some areas is more probably due to a lack of data rather than a real absence while
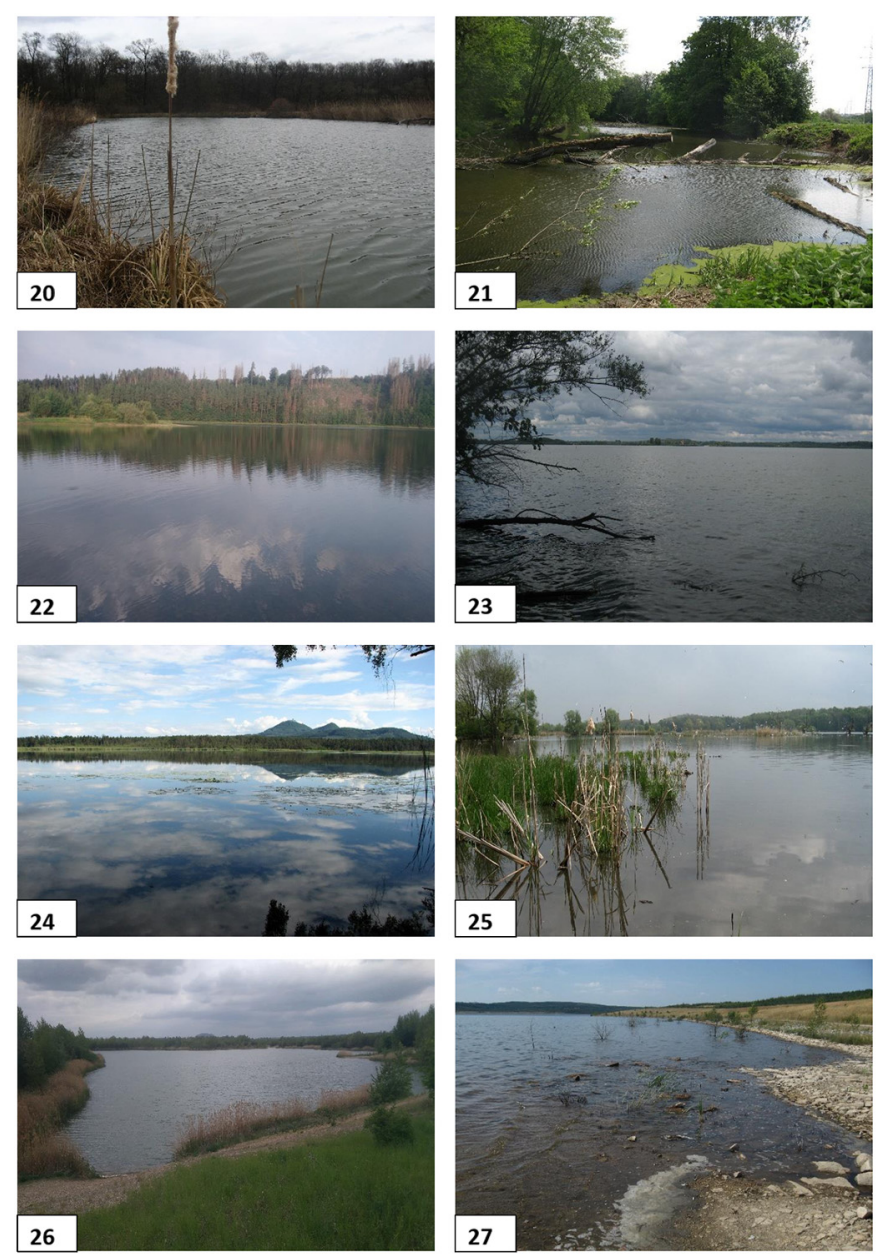

Figs. 20-27. Stagnant waters. 20-21 Oxbows. 20-pool in the Morava River floodplain, A. cygnea. 21-old oxbow of the Labe River near Pardubice. Many oxbows are too old and without occurrence of unionids. 22-23 Dam reservoirs. 22-Želivka dam water reservoir is inhabited by very abundant population of invasive $D$. polymorpha. $U$. pictorum, A. anatina. 23-shallow and extensive Nové Mlýny dam water reservoirs were built near the confluence of rivers Dyje, Svratka and Jihlava on the place of valuable floodplain forest. U. pictorum, $U$. tumidus, A. anatina, A. cygnea. 24-25-Fishponds. 24-Břehynský rybník pond in Kokořínsko - Máchuv kraj Protected Landscape Area. Some fishponds situated in protected areas are still suitable for abundant populations of unionids. U. pictorum, A. anatina, A. cygnea. 25-Kotvice fishpond in the Odra River floodplain in Poodři Protected Landscape Area. A. cygnea. 26-27-Sandpits and quarries. 26Sandspit near Sadská in the Labe River floodplain. Sandspits in floodplains can substitute disappearing oxbows. U. pictorum, $U$. tumidus, A. anatina. 27-Artificial Lake Medard. These habitats are still without unionids but can become suitable habitats for abundant populations of unionids that inhabit standing waters. All photos by author.

the distribution of A. cygnea shows an affinity to lower altitudes and areas with concentration of fishpond systems (e.g. South Bohemia). S. woodiana has been more common in lower altitudes but due to the frequent transport of fish with parasitic larvae (glochidia) this clam has been found often in ponds outside of lowlands. This species was found in the Czech 
Table 2. Densities of unionids in selected local studies.

\begin{tabular}{|c|c|c|c|c|}
\hline \multirow[t]{2}{*}{ Species } & \multicolumn{4}{|c|}{ Density (specimens $/ \mathrm{m}^{2}$ ) } \\
\hline & Douda et al. (2015) & Beran (2015) & Peterka (2010) & Peterka and Čech (2005) \\
\hline U. crassus & & $0.03-0.26$ & $0-0.07$ & \\
\hline U. pictorum & $0-0.4$ & $0.02-0.58$ & $0.17-1.5$ & $0.0003-0.008$ \\
\hline U. tumidus & & & $0.14-2.6$ & $0-0.006$ \\
\hline A. anatina & $0.4-8.8$ & $0.01-0.83$ & $0.38-1.8$ & $0.0003-0.018$ \\
\hline A. cygnea & & & $0-0.1$ & $0-0.001$ \\
\hline P. complanata & $0.4-2.8$ & $0.01-0.02$ & $0.06-0.21$ & \\
\hline
\end{tabular}

Republic for the first time in 1996 (Beran, 1997) and its further spread and settlement of a large part of the Czech Republic can be expected.

\subsection{Changes in distribution}

The main reason for significant increasing of amount of mapping fields and data for all species except $U$. crassus (Figs. 8 and 9) is a gradual increase of the intensity of research especially in last time period. This fact is obviously evident from the comparison of the total number of data entries on the occurrence of molluscs in different time periods from both main sources with number of data entries on unionids (see Sect. 2). Especially in the case of the last time period there is a great increase in the volume of data about molluscs in general which resulted in the correspondingly larger volume of data entries about unionids. An exception is the number of mapping fields in the case of $U$. crassus. The number of mapping fields with the occurrence of this species in the last period has decreased significantly despite the fact that its occurrence has recently been given a great deal of attention which leads to the increase of data but mostly from already known sites and areas while revision of most of historical sites usually did not bring positive results. Its disappearance from extensive areas is also clearly visible from Figure 1 in contrast with the fact that this species was probably the most common and widespread species of genus Unio in the past and farmers used this species as livestock feed (Uličný, 1892-95).

The significant increase in number of mapping fields and data for $S$. woodiana in recent years is caused by quick spread of this species in addition to the intensity of research. This species was found for the first time in the Czech Republic in 1996 (Beran, 1997) and has been able to occupy an extensive part of the Czech Republic in twenty years.

$P$. complanata probably died out in the central section of the Labe (Elbe) River because data about its occurrence there exists from the first time period only even though this area has been intensively researched over the last 20 years (e.g. Beran, 2005; Kolaříková et al., 2014).

Despite of the significant increase in number of mapping fields, data and discovery of many new sites with populations of endangered unionids in last 20 years many local studies of aquatic molluscs confirmed the decrease of populations and diversity of unionids from different parts of the Czech Republic. Beran (2017b) summarized data from the Vysočina Region (Bohemian-Moravian Highlands, $6800 \mathrm{~km}^{2}$ ) and the extinction of populations of $U$. crassus and $U$. tumidus in several rivers or brooks was confirmed in comparison with historical records. The same author confirmed unfavourable situation of population of $U$. crassus in the Lužnice River in South Bohemia (Beran, 2012a), Moravská Dyje in South Moravia (Beran, 2008) and extinction of this species e.g. in the Labe River (Beran, 2005) or in the Rakovnický potok Brook (Beran, 2011a) or in the brook Struha (Beran, 2011c). The extinction of this species from particular sections of brooks or rivers has been confirmed in several cases (e.g. Beran, 2011b, 2013a) while the increase of its population compared to previous studies was recorded only rarely (Beran, 2012b).

\subsection{Populations}

The recorded density of populations was usually very low. It was possible to compare these results with the results of some selected local studies summarized in Table 2. Douda et al. (2015) studied density of unionids at 4 sampling sites of the Vltava River in Prague (during a water level drop due to manipulation). In the case of $P$. complanata this is probably the largest population in the Czech Republic. Beran (2015) conducted a survey and transfer of unionids during the drop of water level of the Ohře River in Terezín. Peterka (2010) studied population densities at 6 sampling sites also during the water level drop of the Kořensko dam reservoir at confluence of rivers Vltava and Lužnice and the same author also studied confluence of rivers Vltava and Malše in České Budějovice at 4 sampling sites (during water level drop) (Peterka and Čech, 2005). Data in these local studies was obtained during water level drop due to manipulation with the water level and in the case of bigger water streams or reservoirs these results are more accurate than data obtained by research performed usually during normal water level. In spite of this the results correspond to the author's results and demonstrate the dominance of low-density populations.

Due to the absence of data about population densities in the past it is very difficult to evaluate possible changes in densities of populations of unionids in the Czech Republic. It can be only assumed that population densities of unionids were higher at many suitable sites as documented Uličný (1892-95) who described the use of bodies of $U$. crassus as livestock feed in the Lužnice River due to its high density.

\subsection{Anthropogenic factors affecting unionids}

While the natural conditions briefly described in one of previous chapters (Aquatic habitats) influence the distribution 
of unionids in general, the changes in the distribution and in many cases also low densities of populations are caused mostly by anthropogenic factors.

Lopes-Lima et al. (2017) mentioned and described habitat loss, fragmentation and degradation; overexploitation; pollution and eutrophications; loss of fish hosts; invasive species; water abstraction and climate change as major threats for freshwater mussels in Europe. Except for overexploitation all mentioned threats are also the main causes of the threat of unionids in the Czech Republic. Anthropogenic factors in the text below are ranked according to assumed significance. Most of these factors do not act alone and the populations of bivalves from family Unionidae are usually affected by the cumulation and/or combination of more these factors. These factors usually have a negative impact on populations of unionids, but some of them may have some partly positive effects (e.g. creation of suitable habitats).

\subsubsection{Pollution and eutrophication}

Most streams in the Czech Republic are polluted, some of them also heavily polluted. Significant pollution persists in industrially active regions, densely populated areas and in regions with intensive agriculture. Arable land comprises more than $37 \%$ of area of the Czech Republic and large amounts of fertilizers and pesticides are still being used for intensive agriculture. Pollution has probably been the most important threat to unionids and their fish hosts. Unpolluted or slightly polluted water was mostly evaluated only in higher altitudes and mountains (Mertl et al., 2017) but watercourses in mountains are not preferable habitats for most unionids. The pollution along with the degradation of watercourses are cited as the main causes of the threat of $U$. crassus in most of local studies (e.g. Beran, 2011b, 2012a, 2012b, 2012c) and this situation is similar in many places around the world. The pollution is still the most recorded global threat comprising $42 \%$ of all threats for freshwater bivalves listed in the IUCN Red List (Lopes-Lima et al., 2018). The pollution, hydrotechnical constructions, invasive species and climatic changes are also mentioned as main causes of decrease of diversity of unionids in Romania (Sîrbu and Benedek, 2017).

Most fishponds inhabited in the past with extensive populations of unionids have been intensively exploited. Eutrophication, high fish stock and manipulation with water level (especially long-term emptying) are probably the main reasons for significant decline of populations of most unionids including common A. anatina. Also the recent occurrence of Unio in fishponds is uncommon in comparison with situation in the past (Uličný, 1892-95).

\subsubsection{Habitat loss, fragmentation, degradation and other changes of habitats}

Most watercourses in the Czech Republic have undergone drastic regulation and were also significantly shortened. Major streams have been modified almost all along their length, the same as minor ones in agricultural landscape and human settlements. Essentially these modifications include straightening, creating beds homogeneous in profile and unified in longitudinal slope (Hanel and Lusk, 2005) (Figs. 15-16). Regulations caused not only homogenization of watercourses but usually also cut off connections with older arms, oxbows and pools resulting in negative impacts for unionids and their host fish species. The pressure for new regulations or reconstruction of old alterations is still higher than revitalization efforts. The rivers were fitted with weirs and more than 100 dams and there is still pressure for building new dams. The system of dams changed the character of Vltava, the biggest tributary of the Labe (Elbe) River. Dams change river flow, temperature, amount of sediment and cause not only fragmentation of populations of unionids but also their host fish (see also Lopes-Lima et al., 2017). Changes in molluscan assemblages (including unionids) caused by dams are mentioned also in Horáčková et al. (2014) for the Vltava River, in Beran (2013a) for the Dyje River and in Beran (2015) for the Ohře River. On the other hand, the dams have become an appropriate habitat for numerous populations of unionids preferring standing waters (e.g. Dvořák and Beran, 2004; Beran, 2007c; Horáčková et al., 2014) and their inflow sections are occasionally inhabited by U. crassus (e.g. Beran, 2011a, 2017b). The Lipno dam water reservoir (4870 ha) in Southern Bohemia is situated in altitude of $725 \mathrm{~m}$ a. s. 1. The Vltava River upstream of this reservoir is inhabited by $M$. margaritifera and $A$. anatina while in the reservoir U. pictorum, U. tumidus, A. anatina and A. cygnea were found (Dvořák and Beran, 2004). These species except for $A$. anatina usually prefer nutrient-rich and slowly flowing water bodies and building of the dam water reservoir allowed existence of populations of these bivalves. Similar effect was described from Texas where man's ongoing alteration of lotic with lentic waterbodies favors common unionids, and dramatically reduces habitat for endemics, inhabiting mostly only streams and rivers fauna (Burlakova et al., 2011). Dam construction and other hydrological alterations are considered as one of major threats also for unionids in East and Southeast Asia (Zieritz et al., 2017). Natural system (habitat) modifications such as the construction of dams and channels are one of major cited threats $(20 \%)$ for freshwater bivalves listed in the IUCN Red List (Lopes-Lima et al., 2018).

Weirs also cause changes in river flow and fragmentation of aquatic habitats. Some large rivers were altered for navigation (Fig. 13) and there is high pressure for establishing artificial canals connecting the Labe River with the Odra River and Morava River. These canals would cause further extensive alterations of many watercourses and the connection among molluscan assemblages, species and populations from different river basins and watersheds (North Sea, Baltic Sea, Black Sea) and is mentioned as potential threat e.g. in Beran (2013a).

The construction of millraces and other artificial canals (Fig. 19) on many watercourses in the past had a positive effect on establishing populations especially of endangered U. crassus (e.g. Beran, 2003, 2007a, 2007b; Beran and Douda, 2009) while its occurrence in the main stream was poor or was not observed. These artificial habitats probably provide better conditions for this species (and its fish hosts) than fast running waters with absence of fine sediment. Abundant populations have often been found at these sites (see Sect. 3).

Several natural lakes were dried or destroyed mostly by coal mining in the past. Natural oxbows and pools (Figs. 20-21) in floodplains of large rivers have gradually disappeared after the regulation of most of larger rivers. These habitats are/ were the only natural stagnant waters suitable for unionids. 
Anthropogenic habitats (e.g. flooded quarries and sandpits, fishponds, dam reservoirs) are a partial substitution for that. While especially more extensive sandpits in floodplains of larger rivers are inhabited by abundant populations of unionids (e.g. Beran, 1996, 2002) (Fig. 26) the most extensive reservoirs formed by the flooding of quarries or disused coal mines (Fig. 27) have only existed for a time too short for development of more diverse communities of unionids and most of them are still without unionids (Beran, 2010, 2013b, 2019). In the case of these newly created and extensive habitats it is possible to assume the progressive development of malacocenoses including unionids in the coming years or decades and they have a great chance to become very valuable habitats for abundant populations of unionids that inhabit standing waters.

\subsubsection{Water abstraction and climate change}

The situation with using water in agriculture or industry in the Czech Republic is not so critical in comparison with other especially southern European countries where growing demands for water by agricultural, industrial and recreational activities have caused significant negative impacts on Mediterranean freshwater ecosystems including decline and loss of endemic freshwater biodiversity (Benejam et al., 2010). Otherwise significant fluctuations in precipitations in last years/decades altogether with the drastic changes in the water regime caused by the extensive landscape regulations carried out over the last 70 years have caused more frequent episodic situations with very low flow in many watercourses. Together with high temperatures and probably other factors (pollution) it is the cause of mass death of unionids as was observed in several rivers by the author (e.g. Labe, Ohře) or other malacologists (Lužnice, Douda and Beran, 2009). Drought can also cause drying out of some small watercourses inhabited by unionids including endangered $U$. crassus. Many populations of unionids in dam reservoirs, artificial canals and in rivers upstream of weirs are threatened by the manipulation of water level. Regularly, emptying of several artificial canals of the Bečva River had caused massive death of unionids (mostly $U$. crassus) in the past (Beran, 2003; Beran and Douda, 2009). An example of this may be probably the most numerous population of $P$. complanata found in the Vltava River in Prague which is threatened by the manipulation of water level (Douda et al., 2015).

\subsubsection{Invasive species}

Three non-native bivalves have been known from the Czech Republic (Beran, 2002; Lorencová et al., 2015). While originally ponto-caspian Dreissena polymorpha (Pallas, 1771) was recorded for the first time more than 120 years ago in the Labe River near Ústí nad Labem (Blažka, 1893), first record about the occurrence of $S$. woodiana exists from 1996 from South Moravia (Beran, 1997) and Corbicula fluminea (O. F. Müller, 1774) was first recorded in 1999 from the Labe River near the Czech-German boundaries (Beran, 2000). Recently the first mentioned species occurs mostly in the lowlands of the largest rivers (Labe, Vltava, Morava and Dyje) and their surroundings (Lorencová et al., 2015). In natural habitats such as rivers $D$. polymorpha usually does not occur in densities that could significantly affect other organisms including unionids. Situation in standing waters is very different. Its occurrence is common in sandpits, quarries and dam reservoirs. Especially in sandpits and some dam reservoirs the numerous occurrence of this species can have negative impact on populations of unionids because there is a lack of suitable objects (rocks, stones) in these habitats for attaching and D. polymorpha uses valves of living or dead unionids. Similar Dreissena rostriformis (Deshayes, 1838) has not been detected on the territory of the Czech Republic yet. The nearest locality of this species is the Danube River in Slovakia (Horsák et al., 2018).

After its first record in the Labe River, Asiatic C. fluminea gradually expanded upstream. Apart from the Labe it gradually settled in some tributaries such as Vltava and Ohře. The occurrence was also recorded from some sandpits isolated from own watercourse of the Labe (Beran, 2018). This species was recorded for the first time from Morava River in southeastern part of the Czech Republic belonging to the Danube River basin and its gradual expansion is predicted (Komzák et al., 2018). Its populations are numerous in some localities and are among the dominant molluscs and both empty shells and live individuals can cover the bottom of the watercourse in some places. These situations are relatively rare and usually this species occurs in lower densities and significant negative impact to unionids has not been proven yet. The gradual expansion of this species was observed in the Ohře River and no negative changes in populations of unionids including endangered $U$. crassus have been documented yet in comparison with situation before its expansion (Beran, 2015, author's unpublished records). Corbicula fluminalis (O. F. Müller, 1774) (or C. cf. fluminalis), another non-native species occurring in Europe has not been recorded in the Czech Republic yet.

Dense populations of non-native $S$. woodiana have been recorded especially in fishponds or dam water reservoirs in South Bohemia and in several rivers (e.g. Dyje, Kyjovka) in South Moravia. In these cases $S$. woodiana can compete with native unionids for food, increase resistance to glochidia in potential host fish and serve as vector for introduction of new parasites and diseases (Lopes-Lima et al., 2017; Donrovich et al., 2017; Douda and Čadková, 2018).

The predation of bivalves by non-native mammals is very important negative factor caused by non-native and invasive species in the territory of the Czech Republic. While the predation by a raccoon (Procyon lotor) seems to be marginal and still local (Beran, 2007b, 2015) two non-native rodents (Ondatra zibethicus, Myocastor coypus) have a very significant impact on the unionids. In the past muscrat $(O$. zibethicus) was usually considered as a main predator of unionids in the Czech Republic (Beran, 2015) but its populations have recently decreased and its current impact will be probably less significant. The most important actual predator of unionids has been nutria (M. coypus) which spreads rapidly mainly in lower altitudes. On many sites it is responsible for predation of large numbers of unionids and probably also for decline of their populations including $U$. crassus (Beran, 2017a). The predation can cause significant decline of populations especially in small brooks. Similar efect of this non-native mammal was described not only from other parts of Europe but also from Japan (Kume et al., 2012). Predation by a mink (Neovison vison) has not been recorded yet (Beran, 2015) but it is not possible to exclude it. 


\subsubsection{Loss of fish hosts}

Extensive changes in freshwater ecosystems and land use in the Czech Republic have been also reflected in changes in their ichthyofauna. Especially drastic regulation and fragmentation, pollution and eutrophication of watercourses have negatively affected the native fish communities. These changes have to be taken into account for conservation of unionids while overfishing, considered as one of major threats in several countries of East and Southeast Asia (Zieritz et al., 2017), does not seem to be significant. Although a number of studies were focused on identifying fish hosts of individual species (summarized e.g. in Lopes-Lima et al., 2017), some recent studies showed complexity of relationship between unionids and their fish hosts. Douda et al. (2014) described differences in the ability of $U$. crassus to infest particular fish species between nearby and recently isolated mussel populations while Douda et al. (2013) showed that the mixing of regional fish biotas may lead to an excessive loss of host availability even for host generalists such as the freshwater mussel A. anatina, with potentially broad consequences for their population dynamics.

\subsubsection{Overexploitation}

In the past shells of Unio spp. were used as material for buttons but much less often than $M$. margaritifera from family Margaritiferidae. At some sites unionids were so frequent that they were use as livestock feed (Uličný, 1892-95). These activities may be responsible for local declines but in the past only. Currently no similar activities exist. Author has been several times asked for opinion by the Police or Czech Environmental Inspectorate in the cases when larger amount of unionids were picked usually by people from the Chinese and Vietnamese communities who use mussels as food. These cases are rare and marginal in comparison with other current threats. The overexploitation together with invasive alien species, urban development, agriculture, climate change and mining comprising less than $10 \%$ of all threats for all freshwater bivalves listed in the IUCN Red List (Lopes-Lima et al., 2018) and also Ferreira-Rodríguez et al. (2019) considered overexploitation as only locally important.

On the basis of the data presented in this study, published and unpublished studies and using professional judgment the author attempted to establish an overview of the influence of threats on particular species except the non-native $S$. woodiana in Table 3. As expected the worst status was estimated for $U$. crassus and $P$. complanata. The possible impact of changes and/or loss of suitable fish hosts is still unclear.

\subsection{Conservation status}

The Proposal of the Red List of aquatic molluscs of the Czech Republic was published in 1995 (Beran, 1995) while the first Red List was mentioned in Beran (1998). Further Red List was published in 2001 (Juřičková et al., 2001) and was actualised in Beran (2002). The first Red List processed by IUCN criteria was published by Beran et al. (2005) and actualised in 2017 (Beran et al., 2017). In all mentioned versions from the Proposal published in 1995 to last version published in 2017 species $U$. crassus and P. complanata are 
listed in category Endangered while $U$. tumidus and A. cygnea are listed as Vulnerable. U. pictorum and A. anatina are considered as Least Concern. Non-native $S$. woodiana was not evaluated and was included in category Not Evaluated as all non-native molluscs. These Red Lists were processed by IUCN criteria and conservation status of particular species corresponds with results presented in this study. Only two species (U. crassus, P. complanata) which are considered endangered in the Czech Republic are also listed in the IUCN Red List of Threatened Species as threatened. U. crassus is listed as Endangered (Lopes-Lima et al., 2014) and P. complanata as Vulnerable (Van Damme, 2011) while other species are listed as Least Concern.

Three species (U. crassus, U. pictorum, A. cygnea) are protected as specially protected animals by Act No. 114/1992 Coll. on the Nature and Landscape Protection. Recently changes in list of specially protected plants and animals have been prepared and the new list should correspond more with recent conservation status.

\subsection{Conservation and management measures}

In the second half of the 20th century, there was little information on the status of populations of unionids in the Czech Republic. By the end of the 20th century the volume of information had gradually increased and attention was paid mainly to the search for populations of the endangered $U$. crassus. During this research the volume of data about the occurrence of other unionids has also increased. This survey was intensified at the beginning of the 21 st century in connection with the preparation of the Czech Republic's accession to the European Union and the need for establishment of NATURA 2000 network and Sites of Community Importance (SCI) with populations of this bivalve. Nearly all of the previously known sites with populations of $U$. crassus became SCI (or part of SCI). U. crassus is one of the subjects of protection in $13 \mathrm{SCIs}$ altogether and present in other 8 SCIs. Second endangered species $P$. complanata occurs in 10 SCIs.

Legislative protection of sites with the occurrence of $U$. crassus and other unionids is only the first step in protection of their populations. It also provides sufficient protection against anthropogenic impacts that could significantly damage or destroy these sites (e.g. dam construction). However it is not effective enough to improve the status of these sites. In most of them pollution is disproportionately high and in many cases watercourses were regulated in the past and flow in intensely exploited landscape. It is desirable to restore the whole riverine systems of many watercourses altogether with land use changes.

The accession of the Czech Republic to the EU was the new impulse for monitoring of known sites with the occurrence of $U$. crassus and also for searching of watercourses potentionally suitable for this species. Several sites with the occurrence of numerous populations have been found since 2004. Many of them remain unprotected just like many other valuable sites with the noteworthy occurrence of other unionids. An example of this may be probably the most numerous population of $P$. complanata found in the Vltava River in Prague (Douda et al., 2015).
In addition to the increase in knowledge of distribution, relationships between unionids and their fish hosts have been studied (e.g. Douda et al., 2012; Donrovich et al., 2017; Douda et al., 2013; Douda et al., 2014). This brings a great deal of new information relevant for the planning of conservation measures. However, it is important to note that the major threats - the pollution and regulation of our watercourses, remain essential for the restoration of numerous populations of unionids.

Due to their largeness (and their visible massive death) unionids are often saved during (or before) different anthropogenic interventions such as long-term emptying of different waterbodies or sediment removal. Unionids have been usually picked up and transferred to other places from sites threatened by anthropogenic interference. Particularly in the past these actions were often chaotic and without expert support. There are also confirmed cases where populations of non-native $S$. woodiana were saved and transmitted e.g. approximately 500 individuals of this species were saved after flood in 2006 and transferred back into the Dyje River in South Moravia (author's unpublished data). For this reason the methodology for carrying out transfers from endangered sites was prepared (Beran, 2011d).

\section{Conclusions}

Altogether 7 species (6 autochthonous, 1 allochthonous) of family Unionidae have been known from the territory of the Czech Republic. All these species occurred in all three different river basins (Labe, Odra, Danube) and watersheds (North, Baltic and Black sea).

Large volume of data about the occurrence of bivalves has been available. This data allows us to understand their distribution as well as changes caused by anthropogenic effects. At the same time the amount of information based on the influence of various factors on their populations is increasing. Many sites with their occurrence are currently part of NATURA 2000 network as Sites of Community Importance (SCIs) or part of other protected areas. Despite the increasing amount of information and conservation measures it is clear that the reduction the pollution, restoration of riverine systems with surrounding alluvium, removal of migratory barriers, improving the water regime with regard to climate change and elimination of the non-native species affecting native unionids are most important for their protection.

Acknowledgements. The author would like to thank Jan Vrba for drawing maps, Michal Horsák for providing his data, Veronika Hamilton for language corrections and anonymous reviewers for their valuable comments.

\section{References}

AOPK ČR. 2013. Záchranný program perlorodky říční (Margaritifera margaritifera) v České republice. Praha: AOPK ČR, 77p.

Araujo R, Buckley D, Nagel KO, Ricardo GJ, Machordom A. 2018. Species boundaries, geographic distribution and evolutionary history of the Western Palearctic freshwater mussels Unio (Bivalvia: Unionidae). Zool J Linn Soc 182: 275-299. 
Benejam L, Angermeier PL, Munne A, García-Berthou E. 2010. Assessing effects of water abstraction on fish assemblages in Mediterranean streams. Freshw Biol 55: 628-642.

Beran L. 1995. Návrh Červeného seznamu měkkýšu České republiky, část 1. - vodní měkkýši. Proposed Red List of molluscs in the Czech Republic. Part 1-Water molluscs. Ochrana prírody 2: $41-44$.

Beran L. 1996. Vodní měkkýši vybraných štěrkopískoven ve Středním Polabí. Muzeum a Současnost 10: 3-8.

Beran L. 1997. First record of Sinanodonta woodiana (Mollusca: Bivalvia) in the Czech Republic. Acta Soc Zool Bohem 61: $1-2$.

Beran L. 2000. First record of Corbicula fluminea (Mollusca: Bivalvia) in the Czech Republic. Acta Soc Zool Bohem 64: 1-2.

Beran L. 2002. Vodní měkkýši České republiky - rozšíření a jeho změny, stanoviště, šíření, ohrožení a ochrana, červený seznam. Aquatic molluscs of the Czech Republic - distribution and its changes, habitats, dispersal, threat and protection, Red List. Sbornik přirodovědného klubu v Uh. Hradišsti, Supplementum 10: $1-258$.

Beran L. 2003. Vodní měkkýši náhonu Strhanec (střední Morava). Bulletin Lampetra V. 5: 22-26.

Beran L. 2005. Vodní měkkýši Labe mezi Pardubicemi a Hřenskem. Malacol Bohemoslov 3: 78-88.

Beran L. 2007a Příspěvek k poznání vodních měkkýšu Vsetínské Bečvy a okolí (Česká republika). Malacol Bohemoslov 6: 38-47. Online serial at http://mollusca.sav.sk 20-Nov-2007.

Beran L. 2007b. Vodní měkkýši Malé Bečvy (Česká republika). Malacol Bohemoslov 6: 29-34. Online serial at http://mollusca.sav.sk 7-September-2007.

Beran L. 2007c. Vodní měkkýši přehradní nádrže Slapy (Česká republika). Malacol Bohemoslov 6: 11-16. Online serial at http:// mollusca.sav.sk 15-March-2007.

Beran L. 2008. Vodní měkkýši Moravské Dyje. Acta Rerum Natural 4: 93-96.

Beran L. 2010. Vodní měkkýši bývalého lomu Chabařovice v severních Čechách. Malacol Bohemoslov 9: 26-32. Online serial at http://mollusca.sav.sk 16-November-2010.

Beran L. 2011a. Př́spěvek k poznání měkkýšu CHKO Křivoklátsko. Bohemia centralis 31: 219-235.

Beran L. 2011b. Příspěvek k poznání vodních měkkýšu evropsky významné lokality Bystřice se zaměřením na populaci velevruba tupého (Unio crassus). Malacol Bohemoslov 10: 10-17. Online serial at http://mollusca.sav.sk 1-Mar-2011.

Beran L. 2011c. Vodní měkkýši dolního toku Struhy na Pardubicku. V̌́. sb. př́r. Práce a studie 18: 155-158.

Beran L. 2011d. Záchranné transfery vodních měkkýšu. Krása našeho domova podzim-zima 2011: 2-4.

Beran L. 2012a. Vodní malakofauna dolního toku Lužnice se zaměřením na stav populace velevruba tupého (Unio crassus). Malacol Bohemoslov 11: 13-21. Online serial at http://mollusca. sav.sk 29-Feb-2012.

Beran L. 2012b. Vodní malakofauna př́toku Javorky u Lázní Bělohrad. Malacol Bohemoslov 11: 45-53. Online serial at http:// mollusca.sav.sk 14-Dec-2012.

Beran L. 2012c. Vodní měkkýši jihočeské části EVL Vlašimská Blanice se zaměřením na populaci velevruba tupého (Unio crassus). Sbor. Jihočes. Muz. v Čes. Budějovicích 52: 133-142.

Beran L. 2013a. Freshwater molluscs of the Dyje (Thaya) river and its tributaries - the role of these water bodies in expansion of alien species and as a refuge for endangered gastropods and bivalves. Folia Malacol 21: 143-160.
Beran L. 2013b. Vodní měkkýši nově vytvořeného jezera Most v severních Čechách. Malacol Bohemoslov 12: 89-92. Online serial at http://mollusca.sav.sk 1-Dec-2013.

Beran L. 2015. Aquatic molluscs fauna of the Ohře River - an important site of Unio crassus Philipsson, 1788 (Bivalvia: Unionidae) in northwestern Bohemia. Folia Malacol 23: 243-261.

Beran L. 2017a. Nepůvodní druhy vodních měkkýšu v ČR. Fórum Ochrany Prírody 4: 31-34.

Beran L. 2017b. Vodní měkkýši Vysočiny. Malacol Bohemoslov 16: 44-76. Online serial at http://mollusca.sav.sk 25-Apr-2017.

Beran L. 2018. Korbikula asijská - další přistěhovalec dobývá Prahu. Živa 66: 257-258.

Beran L. 2019. Colonisation of the newly-created artificial lake Medard and its surroundings by aquatic molluses. Folia Malacol 27: 91-100.

Beran L, Douda K. 2009. Bečva - nejvýznamnější moravská lokalita velevruba tupého? Ochrana Prírody 64: 19-21.

Beran L, Juřičková L, Horsák M. 2005. Mollusca (měkkýši). In: Farkač J, Král D, Škorpík M. (eds.), Červený seznam ohrožených druhu České republiky. Bezobratlí. Red list of threatened species in the Czech Republic. Invertebrates. Príroda 69-74.

Beran L, Juřičková L, Horsák M. 2017. Mollusca (měkkýši) In: Hejda R, Farkač J, Chobot K. (eds), Červený seznam ohrožených druhu České republiky. Bezobratlí. Red list of threatened species in the Czech Republic. Invertebrates. Př́roda 36: 71-76.

Blažka F. 1893. Do Čech zavlečená slávka: Dreissena polymorpha Pall. Vesmír 22: 177-178.

Burlakova LE, Karatayev AY, Karatayev VA, May ME, Bennet DL, Cook MJ. 2011. Endemic species: contribution to community uniqueness effect of habitat alteration, and conservation priorities. Biol Conserv 144: 155-165.

Donrovich SW, Douda K, Plechingerová V, et al. 2017. Invasive Chinese pond mussel Sinanodonta woodiana threatens native mussel reproduction by inducing cross-resistance of host fish. Aquat Conserv Mar Freshw Ecosyst 27: 1325-1333.

Douda K, Beran L. 2009. Ochrana velevruba tupého v České republice - současný stav, problémy a aktuality. Ochrana Př́rody 64: 16-19.

Douda K, Čadková Z. 2018. Water clearance efficiency indicates potential filter-feeding interactions between invasive Sinanodonta woodiana and native freshwater mussels. Biol Invas 20: 10931098.

Douda K, Horký P, Bílý M. 2012. Host limitation of the thick-shelled river mussel: identifying the threats to declining affiliate species. Animal Conserv 15: 536-544.

Douda K, Hronek J, Beran L, Bílý M. 2015. Vodní měkkýši Vltavy v Praze - habitatové nároky a populační dynamika $\mathrm{v}$ prostředí silně modifikovaného vodního toku. Bohemia Centralis 33: 123-134.

Douda K, Lopes-Lima M, Hinzmann M, et al. 2013. Biotic homogenization as a threat to native affiliate species: fish introductions dilute freshwater mussel's host resources. Divers Distrib 19: 933-942.

Douda K, Sell J, Kubíková-Peláková L, Horký P, Kaczmarczyk A, Mioduchowska M. 2014. Host compatibility as a critical factor in management unit recognition: population-level differences in mussel-fish relationships. $J$ Appl Ecol 51: 1085-1095.

Dvořák L, Beran L. 2004. Remarkable records of aquatic molluscs in the Lipno Reservoir and its environs. Silva Gabreta 10: 97-106.

Ferreira-Rodríguez N, Akiyama YB, Aksenova OV, et al. 2019. Research priorities for freshwater mussel conservation assessment. Biol Conserv 231: 77-87. 
Hanel L, Lusk S. 2005. Ryby a mihule České republiky: rozšíření a ochrana. Fishes and lampreys of the Czech Republic: distribution and conservation. ZO ČSOP Vlašim, $447 \mathrm{p}$.

Horáčková J, Ložek V, Beran L, et al. 2014. Měkkýši údolí Vltavy (Čechy). Malacol Bohemoslov 13: 12-105. Online serial at http:// mollusca.sav.sk 22-Apr-2014.

Horsák M, Čejka T, Juřičková L, et al. 2018. Check-list and distribution maps of the molluscs of the Czech and Slovak Republics. Online at http://mollusca.sav.sk/malacology/checklist. $\mathrm{htm}$. Checklist updated at 10-July-2018, maps updated at 5-August2018.

Hruška J. 1992. The freshwater pearl mussel in South Bohemia: evaluation of the effect of temperature on reproduction, growth and age structure of the population. Arch Hydrobiol 126: 181-191.

Hruška J, Volf O. 2003. 20 let výzkumu a aktivní ochrany perlorodky říční v ČR. Ochrana prírody 58: 168-171.

Juřičková L, Horsák M, Beran L. 2001. Check-list of the molluscs (Mollusca) of the Czech Republic. Acta Soc Zool Bohem 65: 25-40.

Kolaříková K, Horecký J, Liška M, et al. 2014. Benthic macroinvertebrates along the Czech part of the Labe and lower section of the Vltava rivers from 1996-2005, with a particular focus on rare and alien species. Biologia 69: 508-521.

Komzák P, Beran L, Horsák M. 2018. The first record of Corbicula fluminea (O. F. Müller, 1774) in Moravia (SE Czech Republic). Malacol Bohemoslov 17: 28-30. Online serial at http://mollusca. sav.sk 13-Nov-2018.

Kume M, Onoda Y, Negishi NJ, Sagawa S, Nagayama S, Kayaba Y. 2012. Feeding damage by exotic species, nutria (Myocastor coypus), to unionid mussels in a floodplain water-body of the Kiso River, Japan. Biol Inland Waters 27: 41-47.

Lopes-Lima M, Kebapçı U, Van Damme D. 2014. Unio crassus. The IUCN Red List of Threatened Species 2014: e.T22736 A42465628. http://dx.doi.org/10.2305/IUCN.UK 2014-1. RLTS.T22736 A42465628. en. Downloaded on 18 June 2018.

Lopes-Lima M, Sousa R, Geist J, et al. 2017. Conservation status of freshwater mussels in Europe: state of the art and future challenges. Biol Rev 92: 572-607.

Lopes-Lima M, Burlakova LE, Karatayev AY, Mehler K, Seddon M, Sousa R. 2018. Conservation of freshwater bivalves at the global scale: diversity, threats and research needs. Hydrobiologia 810: $1-14$.
Lorencová E, Beran L, Horsáková V, Horsák M. 2015. Invasion of freshwater molluscs in the Czech Republic: time course and environmental predictors. Malacologia 59: 105-120.

Mertl J, Myšková T, Pernicová H, et al. 2017. Souhrnná zpráva o životním prostředí v krajích ČR 2016. CENIA, 44 p.

Peterka J. 2010. Posouzení vlivu prohrábek ve zdržích jezu Hněvkovice a VD Kořensko na druhovou skladbu a ochranné podmínky populací velkých mlžu. Závěr. zpráva, ms., Biologické centrum AV ČR, České Budějovice, 12 pp.

Peterka J, Čech M. 2005. Odhad početnosti velkých mlžu na obnažených březích Malše a Vltavy v Českých Budějovicích dne 26.4.2005. Závěr. zpráva, ms., Biologické centrum AV ČR, České Budějovice, 3 pp.

Pruner L, Míka P. 1996. Seznam obcí a jejich částí v České republice s čísly mapových polí pro sítové mapování fauny. Klapalekiana 32 (Suppl.): 1-175.

Simon OP, Vaníčková I, Bílý M, et al. 2015. The status of freshwater pearl mussel in the Czech Republic: several successfully rejuvenated populations but the absence of natural reproduction. Limnol - Ecol Manag Inland Waters 50: 11-20.

Sirbu I, Benedek AM. 2017. Trends in Unionidae (Mollusca, Bivalvia) comunities in Romania: an analysis of environmental gradients and temporal changes. Hydrobiologia 810: 295-314.

Uličný J. 1892-1895. Měkkýši čeští. Klub přírodovědný, Praha.

Van Damme D. 2011. Pseudanodonta complanata. The IUCN Red List of Threatened Species 2011: e.T18446 A8279278. http://dx. doi.org/10.2305/IUCN.UK 2011-2. RLTS.T18446 A8279278.en. Downloaded on 18 June 2018.

Watters GT. 1997. A synthesis and review of the expanding range of the Asian freshwater mussel Anodonta woodiana (Lea, 1834) (Bivalvia: Unionidae). The Veliger 40: 152-156.

Welter-Schultes FW. 2012. European non-marine molluscs, a guide for species identification. Planet Poster Editions, Göttingen, $679 \mathrm{p}$.

Williams JD, Warren ML, Cummings KS, Harris JL, Neves RJ. 1993. Conservation status of freshwater mussels of the United States and Canada. Fisheries 18: 6-22.

Zieritz A, Bogan AE, Froufe E, et al. 2017. Diversity, biogeography and conservation of freshwater mussels (Bivalvia: Unionida) in East and Southeast Asia. Hydrobiologia 810: 29-44.

Cite this article as: Beran L. 2019. Distribution and recent status of freshwater mussels of family Unionidae (Bivalvia) in the Czech Republic. Knowl. Manag. Aquat. Ecosyst., 420, 45. 